\title{
Mat thickness associated with Didymosphenia geminata and Cymbella spp. in the southern rivers of Chile
}

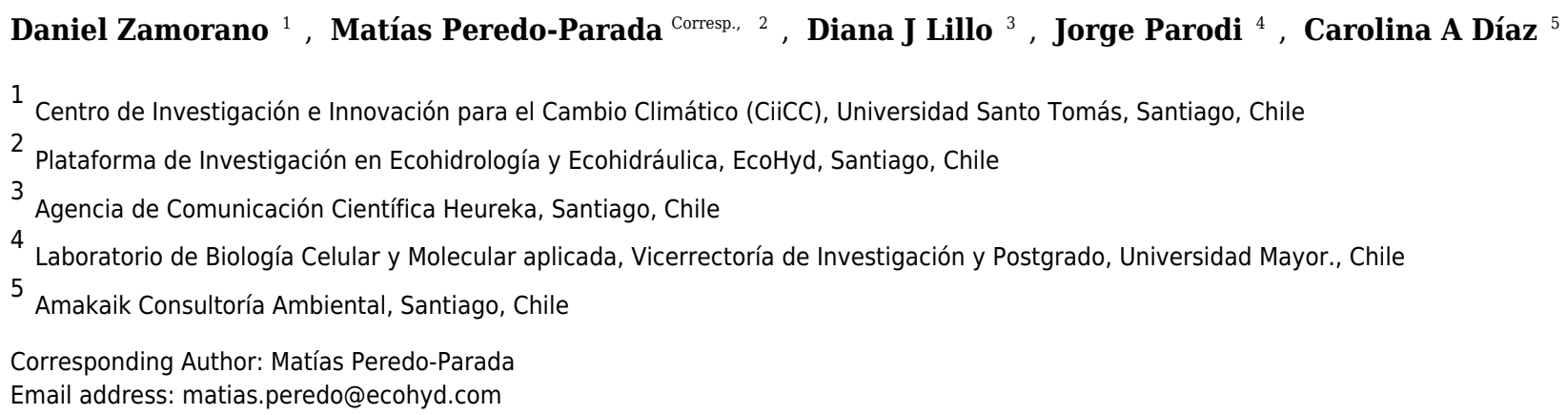

Didymosphenia geminata is a diatom that can alter aquatic systems. Several investigations have shown as chemical, and hydraulic factors have a great influence on the proliferation of $D$. geminata, but the study of other microalgae that could be associated with it has been poorly addressed. The objective of this study is to evaluate the relationship between mat thickness, $D$. geminata and another taxon that produces mucilage, Cymbella, while also considering physical and chemical factors. For this, two samples were taken, one in the spring of 2013 and the other in the autumn of 2014, from eight rivers in central-southern Chile-South America, where the benthic community was characterized, and the thickness of the mat was measured. The results show that the mat thickness on sites with the presence of both taxa is doubled, and while sites with $D$. geminata presence showed mat peak on autumn, sites with Cymbella spp. presence showed on spring. Also, higher values of mat thickness associated with low cell densities of D. geminata and intermediate cell densities of Cymbella spp. Finally, physicochemical variables that better explain mat thickness are phosphorus and water temperature. An alternation process of mucilage production may explain these results by these taxa strongly related to physicochemical variables. The present study contributes evidence about the relationship between mat thickness $D$. geminata and other microalgae contribution, and aquatic condition for this development. 


\title{
Mat thickness associated with Didymosphenia geminata and Cymbella spp. in the southern rivers of Chile
}

\author{
Daniel Zamorano, Matías Peredo-Parada, Diana J. Lillo, Jorge Parodi, Carolina A. Díaz
}

Daniel Zamorano. Centro de Investigación e Innovación para el Cambio Climático (CiiCC), Universidad Santo Tomás, Santiago, Chile. dzamorano@ug.uchile.cl

Matías Peredo-Parada. Plataforma de Investigación en Ecohidrología y Ecohidráulica EcoHyd, Ñuñoa, Chile.matias.peredo@ecohyd.com

Diana J. Lillo. Agencia de Comunicación Científica Heureka, Santiago, Chile. diana.lillo@heurekaonline.com

Jorge Parodi, Laboratorio de Biología Celular y Molecular aplicada, Vicerrectoría de Investigación y Postgrado, Universidad Mayor, Temuco, Chile. jorge.parodi@umayor.cl

Carolina A. Díaz. Amakaik Consultoría Ambiental, Ñuñoa, Chile. carolina.diaz@amakaik.cl

\section{Corresponding author:}

Matías Peredo-Parada, matias.peredo@ecohyd.com

\begin{abstract}
Didymosphenia geminata is a diatom that can alter aquatic systems. Several investigations have shown chemical and hydraulic factors have a great influence on the proliferation of D. geminata, but the study of other microalgae that could be associated with it has been poorly addressed. The objective of this study is to evaluate the relationship between mat thickness, D. geminata and another taxon that produces mucilage, Cymbella, while also considering physical and chemical factors. For this, two samples were taken, one in the spring of 2013 and the other in the autumn of 2014, from eight rivers in central-southern Chile-South America, where the benthic community was characterized, and the thickness of the mat was measured. The results show that the mat thickness on sites with the presence of both taxa is doubled, and while sites with D. geminata presence showed mat peak on autumn, sites with Cymbella spp. presence showed a spring maximum. Also, higher values of mat thickness associated with low cell densities of D. geminata and
\end{abstract}


intermediate cell densities of Cymbella spp. Finally, physicochemical variables that better explain mat thickness are phosphorus and water temperature. An alternation process of mucilage production may explain these results by these taxa strongly related to physicochemical variables. The present study contributes evidence about the relationship between mat thickness, D. geminata and other microalgae contribution, and aquatic condition for this development.

\section{INTRODUCTION}

Since the beginning of the 2000s, massive mat proliferation in oligotrophic rivers by the extracellular stalk material of Didymosphenia geminata (Lyngbye) A. Schmidt has aroused the interest of scientists and governmental entities due to its economic impacts (Beville, Kerr \& Hughey, 2012) and its ability to severely affect conditions in aquatic systems (Spaulding \& Elwell, 2007). For example, D. geminata mats can alter river community composition and food web structure, favoring some species over others (Kilroy, Larned \& Biggs, 2009; Gillis \& Chalifour, 2010; Knorp \& Murdock, 2017; Ladrera, Gomà \& Prat, 2018). Additionally, in periphytic algae, the mat matrix allows carbon fixation at rates typical of higher nutrient inputs (Aboal, Marco, Chaves, Mulero, \& García-Ayala, 2012; Tyler, McGlathery, \& Anderson, 2003), and there is a link between stalk biomass and rates of phosphoester hydrolysis (Aboal et al., 2012; Bray, O'Brien, \& Harding, 2017). Likewise, D. geminata mats reduce stresses and turbulent velocity fluctuations on riverbeds, which may reduce the risk of mat detachment (Larned, Packman, Plew, \& Vopel, 2011), persisting up to one month following a peak in growth (Miller et al., 2009).

The massive growth of $D$. geminata mats has been related to chemical, physical and biological variables that control its presence or the conditions of its proliferation. For example, the presence of nitrogen-fixing cyanobacteria (Novis, Schallenberg \& Smissen, 2016) and levels of dissolved reactive phosphorus (Bothwell, Taylor \& Kilroy, 2014; Bray et al., 2017) favor D. geminata blooms, while an increase in riverbed shear stress favors mat removal (Cullis, Crimaldi \& McKnight, 2013) as well as sediment transport, both of which are conditioned by increased flow (Miller et al., 2009).

Although other diatoms can generate stalks or tubes of mucilage (Bahls, 2007), the possible role of these diatoms as massive mat producers in a possible synergistic relationship with $D$. geminata has rarely been studied. Researchers have recorded other microalgae species able to produce mats through macroscopic visual records on rivers and analysis at the microscopic scale of stalks (Bahls, 2007; Suzawa, Seino \& Mayama, 2011; Khan-Bureau et al., 2014, 2016; Furey, Kupferberg \& Lind, 2014). However, there are few 
publications to date that quantify the relationship between the microalgae community, microalgae density, and mat thickness.

Previous works have already identified species of the genus Cymbella as potentially harmful algae. In the United States, sites with gray mucilage associated with the species C. janischii (A. Schmidt) De Toni have been reported (Bahls, 2007; Khan-Bureau et al., 2014), and in Japan, a country that has not been invaded by D. geminata, algal blooms have also been found associated with C. janischii (Suzawa, Seino \& Mayama, 2011). In several places in Chile, Jaramillo et al. (2015) recorded 7 species of Cymbella together with the presence of $D$. geminata through molecular analysis without detecting the presence of $C$. janischii. The seven species were C. affinis, C. cistula, C. mexicana, C. proximal, C. aspera, C. lanceolata and C. tumida (Brébisson) van Heurck. In none of these studies was the mat thickness estimated to be related to the abundance of species of the genus Cymbella.

In light of this background, the objective of the present study is to evaluate the relationship of D. geminata and Cymbella spp. with mat thickness in rivers in the south-central zone of Chile. For this, three specific objectives are proposed: (I) quantify the mat thickness in different rivers, (II) relate mat thickness with the presence and density of D. geminata and Cymbella spp., and (III) evaluate the relationships among the physical and chemical conditions, mat thickness, D. geminata and Cymbella spp. presence and their density.

\section{MATERIALS AND METHODS}

\section{Study area}

The study was carried out in eight rivers located in four basins in the south-central zone of Chile (Fig. 1) with D. geminata presence records (Montecino et al., 2016). These rivers were selected because they were characterized by circumneutral $\mathrm{pH}$ values, cold and oligotrophic waters and substrates composed mainly of boulders, which are favorable conditions for D. geminata proliferation (Kawecka \& Sanecki, 2003; Spaulding \& Elwell, 2007; Bray, O’Brien \& Harding, 2017). Additionally, these rivers were selected due to the possibility of access and absence of anthropogenic hydrological regulations (dams, large intakes, among others).

Within these rivers, 24 short river reaches of $50 \mathrm{~m}$ were identified and georeferenced. The minimal distance between the selected reaches was $2 \mathrm{~km}$. In each river reach, we selected between 1 and 6 sampling points that represented all the hydromorphological diversity of the river reach, prioritizing the sampling of all the 
87

88

89

mesohabitat types detected (Alcaraz-Hernández et al., 2011). We randomly selected one boulder for each sampling point to obtain the biological samples, which represents the unit of analysis of this study (Fig. 1).

The sampling was carried out on two occasions: late spring (sampling 19 river reaches, 74 sampling points, December 2013) and early autumn (sampling 17 river reaches, 49 sampling points, March 2014). Due to access problems and high flow, only 12 of the 24 river reaches were sampled in both seasons. Given that the hydraulic dynamics of these 12 rivers did not allow the sampling of the same point twice, these sampling points were considered statistically independent from each other. During the late spring season, the water temperature varied between $9{ }^{\circ} \mathrm{C}$ and $18{ }^{\circ} \mathrm{C}$, with an average conductivity of $45.7 \mu \mathrm{S} / \mathrm{cm}$. Meanwhile, the fall season had lower temperatures between $4{ }^{\circ} \mathrm{C}$ and $12{ }^{\circ} \mathrm{C}$ and a higher average conductivity $(52.6 \mu \mathrm{S} / \mathrm{cm})$.

\section{Sampling methods}

Mat thickness was measured with a graduated ruler at each sampling point. To evaluate the microalgae community at each sampling point, one algal biofilm sample of $1 \mathrm{~mL}$ was taken from the mat using a disposable blunt syringe. If the mat layer had a thickness of less than $1 \mathrm{~mm}$, an area of $4 \mathrm{~cm}^{2}$ was swept with a disposable brush, assuming a volume of $0.4 \mathrm{~mL}$. The samples were fixed with $1 \mathrm{~mL}$ of Lugol's iodine in water and stored in sealed $15 \mathrm{~mL}$ containers.

The biological samples were examined quantitatively in the laboratory. For this, a subsample of $1 \mathrm{~mL}$ was obtained and deposited in a Sedgewick-Rafter chamber and analyzed using a Zeiss Axiostar II Plus microscope with inverted objective microscopy set at 40x. We counted almost 100 valves for identification. However, in low abundances samples, we sampled almost three transects of 20 squares of $1 \mathrm{~mm}^{2}$. The identification was performed up to the genus taxonomic level. We used the following works for the taxonomic identifications: Bourrelly, 1970; Parra et al., 1982; Cox, 1996; Round, Crawford \& Mann, 1996; Biggs \& Kilroy, 2000; Bicudo \& Menezes, 2006; Sant'Anna et al., 2006. Finally, richness was calculated with the total taxa detected at the sampling point.

To confirm the identification of $D$. geminata, the samples were oxidized with sulfuric acid based on the methodology described in Battarbee (1986). Once the permanent preparations were obtained, the sample was examined using an Axisostar II Plus optical microscope at 1000x.

Upstream of each river reach sampled, the following physical and chemical parameters were measured using a HANNA Model HI 9828 multiparameter probe: temperature, $\mathrm{pH}$, electrical conductivity (EC) and dissolved oxygen (DO). In addition, samples were taken to estimate the levels of calcium (Ca), total phosphorus $(\mathrm{P})$, iron $(\mathrm{Fe})$ and silicate $\left(\mathrm{SiO}_{2}\right)$ through the analysis protocols of "Standard Methods for Examination of Water \& Wastewater" (Apha, 2005). These samples were taken to the laboratory within 48 
118 hours. At each sampling point, the water column depth (depth) was measured using a graduated bar, and 119 the superficial, middle and background flow velocities were measured using a Global Water FP 101 digital 120 flowmeter. For statistical analysis, physical-chemical values lower than the detection limit were 121 transformed to a value between 0 and the detection limit for each variable according to the suggestion by 122 Helsel \& Cohn (1988).

\section{Analysis of D. geminata and Cymbella spp. versus mat thickness}

124

A two-way ANOVA with permutations was performed to determine differences in the mat thicknesses between points with and without D. geminata and Cymbella spp. Two-way ANOVAs were applied from the methodology used by Anderson \& Legendre (1999). Then, a posteriori nonparametric Tukey test was performed using the "mctp" program with the "narpcomp" package (Konietschke et al., 2015). The samples were categorized as presence only (C/A - Cymbella spp. alone or A/D - D. geminata alone), the presence of both $(\mathrm{C} / \mathrm{D})$ and the absence of both taxa (A/A).

A smooth surface model was fitted to evaluate the relationship between mat thickness (independent variable) and the cell densities of D. geminata and Cymbella spp. (predictor variables). The model was adjusted using the "oridsurf" function (Marra \& Wood, 2011) from the "vegan" package (Oksanen et al., 2015) and selecting the REML method (restricted maximum likelihood) to estimate the model smoothing parameters.

Finally, to complement these analyses and consider the temporal scale, we made different plots to compare sampling seasons (spring 2013 and autumn 2014), cell densities and mat thickness according to the presence or absence of D. geminata and Cymbella spp.

\section{Analysis of D. geminata and Cymbella spp. versus the physical and chemical variables}

To relate the physical and chemical conditions to a temporal scale, we carried out a MANOVA with permutation comparing these parameters between the sampling seasons. Then, ANOVA with permutation was performed for each physical and chemical variable, comparing between the sampling seasons. A MANOVA permutation test and posterior test were carried out using the "RVAideMemoire" package (Hervé, 2015). ANOVA was applied from the methodology used by Anderson \& Legendre (1999).

Second, through the one-way ANOVAs and MANOVA with permutations, the values of the physical and chemical parameters were compared according to the categories A/A, A/D, C/A and C/D. A pairwise nonparametric test was performed on the posterior significate. Additionally, linear discriminant analysis (LDA) (Venables \& Ripley, 2002; Ripley, 2007) was performed to determine which of these parameters 
explained the multivariate context (MASS package; Venables \& Ripley, 2002). Additionally, the physical and chemical parameters with significant differences were correlated with the total richness of the taxa of each sampling point. According to the temporal and categorical results, plots were generated to complement the analysis.

\section{Analysis of mat thickness versus the other variables}

A random forest (RF) regression model was adjusted to determine the explanatory ability of the physical, chemical, temporal and biological variables on mat thickness, considering all the physical and chemical parameters, sampling seasons, presence or absence and density of D. geminata and Cymbella spp. The random forest analysis (Breiman, 2001) was performed using the "caret" package (Kuhn, 2008). This model was trained using a 5-fold cross-validation scheme. The caret package allows for the fitting and tuning of models. Many predictive and machine learning models have structural or hyperparameters that cannot be directly estimated from the data. For RF models, classification trees may be built using a given number of randomly selected predictors that are named "mtry" (Kuhn \& Johnson, 2013). A hyperparameter such as mtry is usually fixed at a given value when training and calibrating an RF model, which is itself an iterative optimization process. The hyperparameter tuning of an RF model refers to a grid search procedure that allows the algorithm to find the best value of mtry to obtain the best model performance (given a set of calibration and validation data points). In our implementation of RF models, the search for an optimal mtry value spanned the space between 2 and the total number of variables. Thus, the tuning process allowed us to explore a range of values for the RF hyperparameter, further improving the model performance. This generated a final model with the best hyperparameter value for a given search grid, which was selected according to the RMSE parameter (Kuhn \& Johnson, 2013).

All the analyses were performed using R project software 3.3.0 v (R Core Team, 2017). In the supplemental material, a complete database (Table S1), Cymbella spp. and D. geminata microscopic photos and mat macroscopic photos (Figure S1) can be found.

\section{RESULTS}

\section{Mat thickness and taxa}

The average mat thickness was $0.46 \mathrm{~cm}$, with a maximum of $3 \mathrm{~cm}$ and a minimum of $0 \mathrm{~cm}$. In $74 \%$ of the samples, a visible mat was detected $(>0.1 \mathrm{~mm}) ; 78 \%$ of the sampling points had a mat between $0 \mathrm{~cm}$ and $1 \mathrm{~cm}$, and only $10 \%$ of the sampling points had a mat greater than $1 \mathrm{~cm}$. 
178 Of the 123 points sampled, a detection of cells by microscopic counts occurred for $D$. geminata in 89 points

179 (71\%), 25 in autumn (20\%) and 64 in spring (51\%), and for Cymbella spp., 76 points were detected (60\%),

18028 in autumn (22\%) and 48 in spring (38\%). By category, the A/A sampling points occurred 15 times in 181 autumn (12.2\%) and 6 times in spring (4.8\%), the C/A sampling points occurred 9 times in autumn (7.3\%) 182 and 4 times in spring (3.2\%), the A/D sampling points occurred 6 times in autumn (4.8\%) and 20 times in 183 spring (16.3\%), and finally, the C/D sampling points occurred 19 times in autumn (15.4\%) and 44 times in 184 spring (35.7\%).

\section{Mat relationship with $D$. geminata and Cymbella spp.}

Of the C/A sampling points, $75 \%$ did not exceed $3 \mathrm{~mm}$ in mat thickness, with a median of $0 \mathrm{~mm}$, without visible mucilage. In contrast, the median thickness of the A/D sampling points was $3 \mathrm{~mm}$, and the median thickness of the C/D sampling points was $5 \mathrm{~mm}$. Thus, Cymbella spp., in the absence of D. geminata, recorded thinner mats than D. geminata, and in the absence of Cymbella spp., both species together recorded larger mat thicknesses (Fig. 2A).

The ANOVA with permutation showed significant differences between the categories $(\mathrm{p}$ value $=0.02 ; \mathrm{p}$ perm $=0.02)($ Table S1). The posterior Tukey test indicated significant differences between the A/A and $\mathrm{C} / \mathrm{D}$ sampling points $(\mathrm{p}$ value $=0.01$ ). Categories $\mathrm{C} / \mathrm{A}$ and $\mathrm{A} / \mathrm{D}$ did not differ significantly from the remaining points $(\mathrm{A} / \mathrm{A}-\mathrm{C} / \mathrm{A}, \mathrm{p}$ value $=0.96 ; \mathrm{A} / \mathrm{A}-\mathrm{A} / \mathrm{D}, \mathrm{p}$ value $=0.16 ; \mathrm{C} / \mathrm{A}-\mathrm{A} / \mathrm{D}, \mathrm{p}$ value $=0.6 ; \mathrm{A} / \mathrm{D}-$ $\mathrm{C} / \mathrm{D}, \mathrm{p}$ value $=0.64$; and $\mathrm{C} / \mathrm{A}-\mathrm{C} / \mathrm{D}$, p value $=0.19)($ Fig. $2 \mathrm{~A}, 2 \mathrm{~B})$.

The relationship between the mat thickness and the cell density of D. geminata (Fig. 3B) and Cymbella spp. (Fig. 3A) showed an inverse pattern, being less clear in the Cymbella spp. case. Additionally, the relationship of densities between Cymbella spp. and D. geminata was inverse, and higher values of mat thickness were associated with low cell densities of $D$. geminata and intermediate cell densities of Cymbella spp. (Fig. 3C). Finally, the smooth surface of the mat thickness fitted to the relationship of Cymbella spp.D. geminata explained $8.3 \%$ of the deviation, which is considered significant $\left(\mathrm{r}^{2}=0.058, \mathrm{p}\right.$ value $\left.=0.035\right)$.

When comparing between the sampling seasons, the results suggested that the Cymbella spp. cellular density was always greater at the C/D sampling points, regardless of the season (Fig. 4A, 4D). In contrast, the $D$. geminata cellular density showed alternation over the A/D sampling points, being greater in spring and lower in autumn. In the $\mathrm{C} / \mathrm{D}$ sampling points, the $D$. geminata density was always relatively high during both seasons (Fig. 4B, 4E). In spring, the $\mathrm{A} / \mathrm{D}, \mathrm{C} / \mathrm{A}$ and $\mathrm{C} / \mathrm{D}$ sampling points showed high mat thicknesses, and in autumn, only the A/D sampling points indicated this result (Fig. 4C, 4F). 
209

210

211

212

213

214

215

216

217

218

219

220

221

222

223

224

225

226

227

228

229

230

231

232

233

234

235

236

237

238

239

240

MANOVA with permutations detected significant differences between the sampling seasons when considering the physical and chemical variables $(\mathrm{p}$ value $=0.001)$. The variables that significantly varied between the seasons according to the ANOVAs were P (mean: $0.008 \mathrm{mg} / \mathrm{L}$ in autumn; $0.13 \mathrm{mg} / \mathrm{L}$ in spring), temperature (mean: $8.4^{\circ} \mathrm{C}$ in autumn; $13.7^{\circ} \mathrm{C}$ in spring), $\mathrm{EC}$ (mean: $52.5 \mu \mathrm{S} / \mathrm{cm}$ in autumn; $45.7 \mu \mathrm{S} / \mathrm{cm}$ in spring), DO (mean: $9.2 \mathrm{mg} / \mathrm{L}$ in autumn; $10.3 \mathrm{mg} / \mathrm{L}$ in spring), Ca (mean: $6.8 \mathrm{mg} / \mathrm{L}$ in autumn; $6.0 \mathrm{mg} / \mathrm{L}$ in spring), Fe (mean: $0.15 \mathrm{mg} / \mathrm{L}$ in autumn; $0.07 \mathrm{mg} / \mathrm{L}$ in spring) (results ANOVA with permutations in Table $\mathrm{S} 1)$.

When evaluating the differences in the physical and chemical conditions between the A/A, C/A, A/D and C/D categories, MANOVA with permutations detected significant differences between the categories $(p$ value $=0.01$ ). A posterior pairwise test indicated significant differences between the $A / A$ and $C / D$ and between the $\mathrm{A} / \mathrm{A}$ and $\mathrm{A} / \mathrm{D}$ sampling points $(\mathrm{A} / \mathrm{A}-\mathrm{C} / \mathrm{D}, \mathrm{p}$ value $=0.003 ; \mathrm{A} / \mathrm{A}-\mathrm{A} / \mathrm{D}, \mathrm{p}$ value $=0.003)$. Category $\mathrm{C} / \mathrm{A}$ did not differ significantly from the rest $(\mathrm{A} / \mathrm{A}-\mathrm{C} / \mathrm{A}, \mathrm{p}$ value $=0.34 ; \mathrm{C} / \mathrm{A}-\mathrm{A} / \mathrm{D}, \mathrm{p}$ value $=$ 0.43 ; and $\mathrm{C} / \mathrm{A}-\mathrm{C} / \mathrm{D}$, $\mathrm{p}$ value $=0.11$ ).

Regarding the LDA to discriminate between the $\mathrm{A} / \mathrm{A}, \mathrm{C} / \mathrm{A}, \mathrm{A} / \mathrm{D}$ and $\mathrm{C} / \mathrm{D}$ sampling points according the physical and chemical variables, axis 1 explained $85 \%$ of the variance. On axis 1 , discrimination is maximized to the $\mathrm{A} / \mathrm{A}$ and $\mathrm{C} / \mathrm{A}$ sampling points versus the $\mathrm{A} / \mathrm{D}$ and $\mathrm{C} / \mathrm{D}$ sampling points (mean on axis 1 : $\mathrm{A} / \mathrm{A}=-2.06, \mathrm{C} / \mathrm{A}=-0.59, \mathrm{~A} / \mathrm{D}=0.17$ and $\mathrm{C} / \mathrm{D}=0.60$ ). When comparing these values with Table $1, \mathrm{P}$ was strongly related to the $\mathrm{A} / \mathrm{A}$ and $\mathrm{C} / \mathrm{A}$ sampling points (the most negative variable), while $\mathrm{pH}$ and temperature were related to the A/D and C/D sampling points (the most positive variables) (Table 1) (Fig. 5).

When evaluating the differences between the categories by variable, the $\mathrm{pH}, \mathrm{DO}, \mathrm{Ca}, \mathrm{Fe}$, depth and background velocity did not change significantly. On the other hand, the variables that varied between the categories were temperature ( $\mathrm{p}$ ANOVA $<0.001$, p perm $=0.002)$, EC $(\mathrm{p}$ ANOVA $<0.001$, p perm $=$ $0.001), \mathrm{P}(\mathrm{p}$ ANOVA $=0.001, \mathrm{p}$ perm $=0.001)$ and $\mathrm{SiO}_{2}(\mathrm{p}$ ANOVA $<0.001$, p perm $=0.001)($ details of the ANOVAs and MANOVA in Table S1).

When performing the subsequent Tukey test, the water temperature varied between the categories, highlighting the differences between the $\mathrm{A} / \mathrm{A}$ and the $\mathrm{A} / \mathrm{D}-\mathrm{C} / \mathrm{D}$ categories $(\mathrm{A} / \mathrm{A}-\mathrm{A} / \mathrm{D}, \mathrm{p}$ value $=0.004$; and $\mathrm{A} / \mathrm{A}-\mathrm{C} / \mathrm{D}$, $\mathrm{p}$ value $=0.011)$ and the differences between the $\mathrm{C} / \mathrm{A}$ and the $\mathrm{A} / \mathrm{D}-\mathrm{C} / \mathrm{D}$ categories $(\mathrm{C} / \mathrm{A}$ $-\mathrm{A} / \mathrm{D}$, $\mathrm{p}$ value $=0.019 ;$ and $\mathrm{C} / \mathrm{A}-\mathrm{C} / \mathrm{D}, \mathrm{p}$ value $=0.049)$. At the temporal scale, while the $\mathrm{A} / \mathrm{A}$ sampling had colder temperatures in spring, the autumn temperature was similar at all the sampling points (Fig. 6). For $\mathrm{SiO}_{2}$, only differences between the $\mathrm{A} / \mathrm{A}$ and the D. geminata presence sampling points were detected $(\mathrm{A} / \mathrm{A}-\mathrm{A} / \mathrm{D}, \mathrm{p}$ value $<0.001$; and $\mathrm{A} / \mathrm{A}-\mathrm{C} / \mathrm{D}, \mathrm{p}$ value $<0.001)$. On a temporal scale, the $\mathrm{SiO}_{2}$ peak in the $\mathrm{A} / \mathrm{A}$ sampling point during autumn is highlighted. For $\mathrm{P}$ and $\mathrm{EC}$, the only differences occurred between the 
$241 \mathrm{~A} / \mathrm{A}$ and $\mathrm{C} / \mathrm{A}$ sampling points $(\mathrm{P}: \mathrm{A} / \mathrm{A}-\mathrm{C} / \mathrm{D}, \mathrm{p}$ value $=0.015$; and $\mathrm{EC}: \mathrm{A} / \mathrm{A}-\mathrm{C} / \mathrm{D}$, $\mathrm{p}$ value $=0.054)$.

242 Similar to the silica case, the EC showed a peak at the A/A sampling points in autumn. For phosphorous, 243 the sampling points showed higher values in spring and lower values in autumn, but in general, the A/A 244 sampling points always showed higher values (Fig. 6).

245 The correlations between these four parameters and the total richness of the taxa showed that only $\mathrm{SiO}_{2}$ was 246 inversely and significantly related to the total richness, but not the temperature, P and EC (Kendall test: 247 temperature, $\tau=0.12, \mathrm{p}$ value $=0.06 ; \mathrm{SiO}_{2}, \tau=-0.13$, $\mathrm{p}$ value $=0.05 ; \mathrm{EC}, \tau=0.11, \mathrm{p}$ value $=0.09 ;$ and $\mathrm{P}$, $248 \tau=-0.03, \mathrm{p}$ value $=0.61)$.

\section{Mat thickness versus all the predictor variables}

250 According to the RF model, the physical, chemical, temporal and biological variables (density and presence of $D$. geminata and Cymbella spp.) could explain up to $49 \%$ of the variance in the mat thickness (RMSE $=$ $0.41, \mathrm{R}^{2}=0.49$ ), and the variables with the greatest power of discrimination were phosphorus and the $D$. geminata and Cymbella spp. density (Table 1). When we look at the data in detail (Fig. 7), the mat thickness peak occurred at lower P values. We highlight that the mat thickness peak with higher P values occurred exclusively on the C/D sampling points during the spring. Additionally, for Cymbella spp., the C/A mat thickness peak occurred during spring but overall had lower P values.

\section{DISCUSSION}

\section{D. geminata and Cymbella spp. and their relationship with mat}

The results show how the points had different mat thicknesses according to D. geminata and Cymbella spp. presence or absence. In the presence of both, the mat thickness was doubled. However, only with Cymbella spp. presence is it more likely that mats do not become visible $(<0.5 \mathrm{~mm})$. In contrast, only in the presence of $D$. geminata did the sampling points have a visible mat in most cases (median of $3 \mathrm{~mm}$ ). This finding alone could suggest that Cymbella spp. does not have the ability to produce the massive growth that $D$. geminata does. This would imply that mat thickness duplication in the presence of both species does occur through an interaction between both species.

However, when evaluated on a temporal scale, the alternation of the mat thickness peak between the A/D and C/A sampling points in spring and autumn proves how each taxon separately can produce a thick mat and shows that mucilage production depends on both taxa, the physicochemical variables and time. Despite this, the $\mathrm{C} / \mathrm{D}$ sampling points in both seasons had a stable mat thickness, which could suggest an interaction 
271 between the taxa or that the physicochemical variables at these points are advantageous for mucilage

272 production. This last hypothesis agrees with different published papers (Sundareshwar et al., 2011; Kilroy

273 \& Bothwell, 2012; Bothwell, Taylor \& Kilroy, 2014; Montecino et al., 2016)

274 Greater mat thickness at a lower cell density of D. geminata is consistent with the documented paradox 275 between D. geminata and mucilage production, a process associated with low cell abundance (Bothwell, 276 Taylor \& Kilroy, 2014). For Cymbella spp., a greater mat thickness is present at intermediate densities, 277 suggesting the existence of a cellular optimal for the production of mucilage. These results suggest that $D$. 278 geminata could develop mucilage in the early stages of colonization of a habitat or in situations of scarce 279 nutrients, but not Cymbella spp., which would require a certain cell density to produce more mucilage. 280 However, there are no studies investigating the production of mucilage associated with this genus.

281 For D. geminata, the results showed a temporal alternation between the cell density and mat thickness at 282 the sampling points without Cymbella spp., which is in accordance with the literature (Khan-Bureau et al., 283 2014; Bothwell, Taylor \& Kilroy, 2014) and demonstrates the temporal scale of this phenomenon. On the 284 other hand, the results for Cymbella spp. showed that this taxon had an even higher cell density and mat 285 thick in the presence of $D$. geminata, but without $D$. geminata presence the mat thickness peak occurred at 286 a low cell density and during spring. This pattern could indicate how mucilage production in Cymbella spp. 287 is more dependent on physicochemical conditions than its cell density. Currently, there is evidence that cell 288 density alternates with Cymbella species (Khan-Bureau et al., 2014) but does not exist in relation to 289 mucilage production, and thus, the hypothesis about these patterns in Cymbella spp. should be addressed in 290 the future.

291 Regarding the sampling point in the presence of D. geminata and Cymbella spp., we suggest that a high cell density of both taxon and a thicker mat during both seasons would be a consequence of their relationship through the mucilage: D. geminata with a lower cellular density would produce mucilage (increased mat thickness), particularly in autumn, while Cymbella spp. with an intermediate cellular density would produce mucilage in spring, alternating this work and maintaining a constant mat thickness. As we do not have a microscale count of the stalks, we do not have clarity on which species produces mucilage during spring or autumn in the $\mathrm{C} / \mathrm{D}$ sampling points; however, a stable cell density suggests a population in good condition, probably due the mat thickness that generates suitable habitat for these taxa (Ladrera, Gomà \& Prat, 2018).

Previous studies have documented the ability of $D$. geminata mats to generate habitat for small diatoms and other microorganisms (Domozych, Toso \& Snyder, 2010; Ladrera, Gomà \& Prat, 2018) by reducing the 
302 which favors the colonization of cosmopolitan diatoms (Kilroy, Larned \& Biggs, 2009) and is consistent 303 with the pattern detected.

\section{The role of the physical and chemical variables on Cymbella spp. and D. geminata}

305 Examining the physicochemical differences between the categories allow us to construct hypotheses about 306 the niches of both taxa. First, in multivariate analysis, the A/D and C/D sampling points were differentiated 307 from the $\mathrm{A} / \mathrm{A}$ and $\mathrm{C} / \mathrm{A}$ sampling points, suggesting that the realized niche of $D$. geminata is near its 308 fundamental niche, as it was recorded only on the sampling points with the physicochemical variables 309 suitable for its presence. This result is striking considering that $D$. geminata is a novel invasive species in 310 Chile (Reid et al., 2012; Jaramillo et al., 2015; Montecino et al., 2016). In contrast, the C/A sampling points 311 not having significant differences from the other sampling points categories suggests that Cymbella spp. 312 has not colonized all of its suitable sampling points, separating its fundamental niche from its realized niche.

313 This situation raises several questions about the dispersal abilities and historical context for these taxa. The 314 more cited question is about the colonization process of $D$. geminata in Chile: did it arrive recently or was 315 it always there? In the first instance, evidence supports that D. geminata apparently has been in Chile for 316 longer than it seems (the first record was cited in Asprey et al., 1964). However, if we consider its dispersal 317 and colonization skills, this pattern could also be the product rapid dispersion and difficult removal from 318 the rocks that it colonizes. These questions are even more extensive in Cymbella spp., a genus that has just 319 recently been investigated as mat producers both in Chile and in the world (Suzawa et al., 2011; Jaramillo 320 et al., 2015; Khan-Bureau et al., 2016, among others).

321 While the temperature, $\mathrm{P}$, silica and EC varied significantly between the sampling point categories, the 322 temporal scale proves the plasticity of both taxa. For example, in spring, Cymbella spp. and D. geminata 323 apparently could prefer high temperatures, though in autumn, the water in the A/A sampling points was 324 equally as cold as the $\mathrm{C} / \mathrm{A}, \mathrm{A} / \mathrm{D}$ and $\mathrm{C} / \mathrm{D}$ sampling points. For $\mathrm{EC}$ and silica, the differences in values 325 occurred only during autumn, when the A/A sampling points had the highest values compared to the other 326 categories, but in spring, the silica and EC values were similar in all the categories. Only the P variable was 327 consistent in select habitats for these taxa in both seasons, with ever lower values at points with $D$. geminata 328 and Cymbella spp. presence. Thus, the results again show the relevance of phosphorus.

329 The richness of microalgae increased with the phosphorus and EC levels, which was contrary to the pattern 330 recorded in D. geminata and Cymbella spp. This could be interpreted as a pattern that differentiates 331 mucilage producers from other algae. This hypothesis can be supported by the river continuum concept 332 (Vannote et al., 1980). Microalgae that are adapted to headwaters with low flow and watershed areas should 
333

334

335

336

337

338

339

340

341

342

343

344

345

346

347

348

349

350

351

352

353

354

355

356

357

358

359

360

361

362

need the ability to resist turbulent flow and low P levels, with mucilage production being a trait that could even be adaptive. On the other hand, microalgae adapted to river mouths would be adapted to low flow turbulence, low river substrates and higher $\mathrm{P}$ levels without needing mucilage production to attach to river substrates. However, much research is needed to confirm this hypothesis.

Finally, it should be noted that the patterns of silica, phosphorus and EC observed in the presence of Cymbella spp. and D. geminata has previously only been documented for D. geminata and phosphorus (Bray et al., 2017), which coincides with the results presented by Spaulding \& Elwell (2007), where a range of phosphorus levels in D. geminata has frequently been detected in the USA.

\section{The role of physical and chemical variables in mat thickness}

We suggest that the relevance of phosphorus for mat thickness is strongly related to the presence of $D$. geminata and Cymbella spp. The principal antecedent for this hypothesis is the low P levels at the C/A, $\mathrm{A} / \mathrm{D}$ and $\mathrm{C} / \mathrm{D}$ sampling points. There is evidence of a relationship between $\mathrm{P}$ and $D$. geminata (Kilroy \& Bothwell, 2012; Bothwell, Taylor \& Kilroy, 2014). In this work, we add evidence that also relates phosphorus with mat thickness, but we now add Cymbella spp. as an additional taxon. The other variables that explained mat thickness in the random forest were the Cymbella spp. and D. geminata densities. This is relevant for highlighting the role of other taxa, such as Cymbella spp., on the debate about river mats.

The mat thickness recorded was much smaller than that of the mats in countries strongly impacted by $D$. geminata; one open question that this paper suggests is the role of Cymbella spp. in massive D. geminata blooms, since this would be relevant on mat volume and Cymbella spp. would compete with D. geminata, or it could possibly be releveled secondarily. In the second case, the importance of Cymbella spp. in this work could relate that physicochemical conditions do not allow $D$. geminata to make massive amounts of mucilage.

One interesting result is the peak mats at the A/D sampling points in autumn. Is it more favorable s in Chile for D. geminata to produce mucilage in autumn? If the answer is yes, the tourists of these rivers would not visit during the worst mat levels months. Additionally, tourist visits would occur precisely during the highest flows in winter. Both conditions explain why D. geminata does not strongly impact Chilean rivers compared to other countries.

Because there are no limnological data linked to mat thickness in Chile, there is no information to compare or establish the ability of Cymbella spp. to produce mucilage, which highlights the novelty of the present study. 


\section{CONCLUSION}

364 The presence of $D$. geminata and Cymbella spp. increases mat thickness, and the temporal results suggest 365 an alternation process of mucilage production by these taxa. While D. geminata showed a mat peak in 366 autumn, Cymbella spp. showed a peak in spring with a constant thick mat at the C/D sampling points. The 367 presence of both taxa and mucilage production are apparently strongly related to $\mathrm{P}$ and temperature levels, 368 which is consistent with the international literature. The findings of this study suggest that it is necessary 369 to evaluate the microalgae community together when we try to determine the relationship between mucosal 370 development and species. Further research must continue to investigate the processes that determine the 371 biological production of mucilage in rivers.

\section{ACKNOWLEDGEMENTS}

373

375

376

377

378

379

380

381

382

383

384

385

386

387

388

389

390

391

Thank you to Magaly Olivares, Ursula Romero and Leonardo Núñez for her valuable comments and feedback.

\section{REFERENCES}

Alcaraz-Hernández JD., Martinez-Capel F., Peredo-Parada MM., Hernández Mascarell AB. 2011. Mesohabitat heterogeneity in four mediterranean streams of the Jucar river basin (Eastern Spain). Limnetica 30:363-378.

Anderson MJ., Legendre P. 1999. An empirical comparison of permutation methods for tests of partial regression coefficients in a linear model. Journal of Statistical Computation and Simulation 62:271-303. DOI: 10.1080/00949659908811936.

Apha A. 2005. WEF, 2005. Standard methods for the examination of water and wastewater 21:258-259.

Asprey GF., Benson-Evans K., Furet JE. 1964. A contribution to the study of South American freshwater phytoplankton. Universidad de Concepción.

Bahls LL. 2007. Cymbella janischii-Giant endemic diatom of the Pacific Northwest: morphology, ecology and distribution compared to Cymbella mexicana. Northwest Science 81:284-292.

Battarbee RW. 1986. Diatom analysis. Handbook of Holocene palaeoecology and palaeohydrology:527-570.

Beville ST., Kerr GN., Hughey KFD. 2012. Valuing impacts of the invasive alga Didymosphenia geminata on recreational angling. Ecological Economics 82:1-10. DOI: 10.1016/J.ECOLECON.2012.08.004.

Bicudo CE de M., Menezes M. 2006. Gêneros de algas de águas continentais do Brasil: chave para identificação e descrições. Rima.

Biggs BJ., Kilroy C. 2000. Stream periphyton monitoring manual. Niwa.

Bothwell ML., Taylor BW., Kilroy C. 2014. The Didymo story: the role of low dissolved phosphorus in the formation of Didymosphenia geminata blooms. Diatom Research 29:229-236. DOI: 10.1080/0269249X.2014.889041. 
392 Bourrelly P. 1970. Les Algues d'eau douce: Tome III: Les algues bleues et rouges, les Eugléniens, Peridiniens et Cryptomonadines.

393

394

395

396

397

398

399

400

401

402

403

404

405

406

407

408

409

410

411

412

413

414

415

416

417

418

419

420

421

422

423

Bray J., Kilroy C., Gerbeaux P., Harding JS. 2017. Ecological eustress? Nutrient supply, bloom stimulation and competition determine dominance of the diatom Didymosphenia geminata. Freshwater Biology 62:1433-1442. DOI: $10.1111 /$ fwb. 12958 .

Bray J., O'Brien J., Harding JS. 2017. Production of phosphatase and extracellular stalks as adaptations to phosphorus limitation in Didymosphenia geminata (Bacillariophyceae). Hydrobiologia 784:51-63. DOI: 10.1007/s10750-016-2851-2.

Breiman L. 2001. Random Forests. Machine Learning 45:5-32. DOI: 10.1023/A:1010933404324.

Cox EJ. 1996. Identification of freshwater diatoms from live material. Chapman \& Hall.

Cullis JD., Crimaldi JP., McKnight DM. 2013. Hydrodynamic shear removal of the nuisance stalk-forming diatom Didymosphenia geminata. Limnology and Oceanography: Fluids and Environments 3:256-268.

Domozych DS., Toso M., Snyder A. 2010. Biofilm dynamics of the nuisance diatom, Didymosphenia geminata (Bacillariophyceae). Nova Hedwigia:249-259.

Furey PC., Kupferberg SJ., Lind AJ. 2014. The perils of unpalatable periphyton: Didymosphenia and other mucilaginous stalked diatoms as food for tadpoles. Diatom Research 29:267-280. DOI: 10.1080/0269249X.2014.924436.

Gillis C-A., Chalifour M. 2010. Changes in the macrobenthic community structure following the introduction of the invasive algae Didymosphenia geminata in the Matapedia River (Québec, Canada). Hydrobiologia 647:63-70. DOI: 10.1007/s10750-0099832-7.

Helsel DR., Cohn TA. 1988. Estimation of descriptive statistics for multiply censored water quality data. Water Resources Research 24:1997-2004. DOI: 10.1029/WR024i012p01997.

Hervé M. 2015. RVAideMemoire: Diverse basic statistical and graphical functions. R package version 0.9-45-2. Computer software.

Jaramillo A., Osman D., Caputo L., Cardenas L. 2015. Molecular evidence of a Didymosphenia geminata (Bacillariophyceae) invasion in Chilean freshwater systems. Harmful Algae 49:117-123. DOI: 10.1016/J.HAL.2015.09.004.

Kawecka B., Sanecki J. 2003. Didymosphenia geminata in running waters of southern Poland-symptoms of change in water quality? Hydrobiologia 495:193-201.

Khan-Bureau DA., Beauchene MS., Ector L., Morales EA., Lewis LA. 2014. Observations of two nuisance stalk-forming diatoms (Bacillariophyta) from a river in Connecticut, Northeastern USA: Didymosphenia sp. and Cymbella janischii (A. Schmidt) De Toni. BioInvasions Records 3:139-149.

Khan-Bureau DA., Morales EA., Ector L., Beauchene MS., Lewis LA. 2016. Characterization of a new species in the genus Didymosphenia and of Cymbella janischii (Bacillariophyta) from Connecticut, USA. European Journal of Phycology 51:203-216. DOI: 10.1080/09670262.2015.1126361.

Kilroy C., Bothwell ML. 2012. Didymosphenia geminata growth rates and bloom formation in relation to ambient dissolved 
phosphorus concentration. Freshwater Biology 57:641-653.

425

426

427

428

429

430

431

432

433

434

435

436

437

438

439

440

441

442

443

444

445

446

447

448

449

450

451

452

453

454

455

456

Kilroy C., Larned ST., Biggs BJF. 2009. The non-indigenous diatom Didymosphenia geminata alters benthic communities in New Zealand rivers. Freshwater Biology 54:1990-2002. DOI: 10.1111/j.1365-2427.2009.02247.x.

Knorp NE., Murdock JN. 2017. Effects of the nuisance alga Didymosphenia geminata on benthic community resource use. Proceedings of Student Research and Creative Inquiry Day 1.

Konietschke F., Placzek M., Schaarschmidt F., Hothorn LA. 2015. nparcomp : An $R$ Software Package for Nonparametric Multiple Comparisons and Simultaneous Confidence Intervals. Journal of Statistical Software 64. DOI: 10.18637/jss.v064.i09.

Kuhn M. 2008. Building Predictive Models in R Using the caret Package. Journal of Statistical Software 28:1-26. DOI: 10.18637/jss.v028.i05.

Kuhn M., Johnson K. 2013. Applied Predictive Modeling. New York, NY: Springer New York. DOI: 10.1007/978-1-4614-68493.

Ladrera R., Gomà J., Prat N. 2018. Effects of Didymosphenia geminata massive growth on stream communities: Smaller organisms and simplified food web structure. PLOS ONE 13:e0193545. DOI: 10.1371/journal.pone.0193545.

Larned ST., Packman AI., Plew DR., Vopel K. 2011. Interactions between the mat-forming alga Didymosphenia geminata and its hydrodynamic environment. Limnology and Oceanography: Fluids and Environments 1:4-22. DOI: 10.1215/215736981152081.

Marra G., Wood SN. 2011. Practical variable selection for generalized additive models. Computational Statistics \& Data Analysis 55:2372-2387. DOI: 10.1016/J.CSDA.2011.02.004.

Miller MP., McKnight DM., Cullis JD., Greene A., Vietti K., Liptzin D. 2009. Factors controlling streambed coverage of Didymosphenia geminata in two regulated streams in the Colorado Front Range. Hydrobiologia 630:207-218. DOI: 10.1007/s10750-009-9793-x.

Montecino V., Molina X., Bothwell M., Muñoz P., Carrevedo ML., Salinas F., Kumar S., Castillo ML., Bizama G., Bustamante RO. 2016. Spatio temporal population dynamics of the invasive diatom Didymosphenia geminata in central-southern Chilean rivers. Science of the Total Environment 568:1135-1145.

Novis P., Schallenberg M., Smissen R. 2016. Aquatic nitrogen-fixing cyanobacteria associated with blooms of Didymosphenia geminata: insights from a field study. Hydrobiologia 770:37-52.

Oksanen J., Blanchet FG., Kindt R., Legendre P., Minchin PR., O’hara RB., Simpson GL., Solymos P., Stevens MHH., Wagner H. 2015. vegan: Community Ecology Package. R package version 2.0-10. 2013. There is no corresponding record for this reference.

Parra O., González M., Dellarossa V., Rivera P., Orellana M. 1982. Manual taxonómico del fitoplancton de aguas continentales. Concepción: Editorial Universidad de Concepción.

R Core Team. 2017. R: A language and environment for statistical computing. Vienna, Austria: R Foundation for Statistical Computing; 2014. 
457

458

459

460

461

462

463

464

465

466

467

468

469

470

471

472

473

474 475
Reid BL., Hernández KL., Frangópulos M., Bauer G., Lorca M., Kilroy C., Spaulding S. 2012. The invasion of the freshwater diatom Didymosphenia geminata in Patagonia: prospects, strategies, and implications for biosecurity of invasive microorganisms in continental waters. Conservation Letters 5:432-440.

Ripley BD. 2007. Pattern recognition and neural networks. Cambridge university press.

Round FE., Crawford RM., Mann DG. 1996. Diatoms: biology and morphology of the genera. Cambridge university press.

Sant'Anna CL., Azevedo MT., Agujaro LF., Decarvalho LRM., Souza RCR. 2006. Manual ilustrado para identificação e contagem de cianobactérias planctônicas de águas continentais brasileiras. Interciência; São Paulo: Sociedade Brasileira de Ficologia.

Spaulding S., Elwell L. 2007. Increase in nuisance blooms and geographic expansion of the freshwater diatom Didymosphenia geminata: recommendations for response. White Paper. USEPA Region 8.

Sundareshwar P V., Upadhayay S., Abessa M., Honomichl S., Berdanier B., Spaulding SA., Sandvik C., Trennepohl A. 2011. Didymosphenia geminata : Algal blooms in oligotrophic streams and rivers. Geophysical Research Letters 38:n/a-n/a. DOI: 10.1029/2010GL046599.

Suzawa T., Seino S., Mayama S. 2011. Blooms of Cymbella janischii (AWF Schmidt) De Toni accompanied by Gomphoneis minuta (Stone) Kociolek and Stoermer from the upper stream of the Chikugo River, Kyushu, Japan: possibility of new alien diatom species. Diatom 27:58-64.

Vannote RL., Minshall GW., Cummins KW., Sedell JR., Cushing CE. 1980. The River Continuum Concept. Canadian Journal of Fisheries and Aquatic Sciences 37:130-137. DOI: 10.1139/f80-017.

Venables WN., Ripley BD. 2002. Modern Applied Statistics with S. New York, NY: Springer New York. 


\section{Figure 1}

Study area and sampling scheme

(A) Study rivers and sampled river reaches. A total of 25 river reaches were sampled during two seasons (spring and autumn). A/A, reaches with absence of both $D$. geminata and Cymbella spp.; $A / D$, reaches with the presence of $D$. geminata only; $C / A$, reaches with the presence of Cymbella spp. only; and C/D, reaches with the presence of both species. (B) Study area. The study was carried out in the regions of Bío-Bío, Araucanía and Los Ríos, in the south-central zone of Chile. Black rectangle represents map A area. (C) Representation of sampled river reaches. In each river reach between 1 and 6 sampling points were registered, with a total of 123 sampling points during both campaigns. 


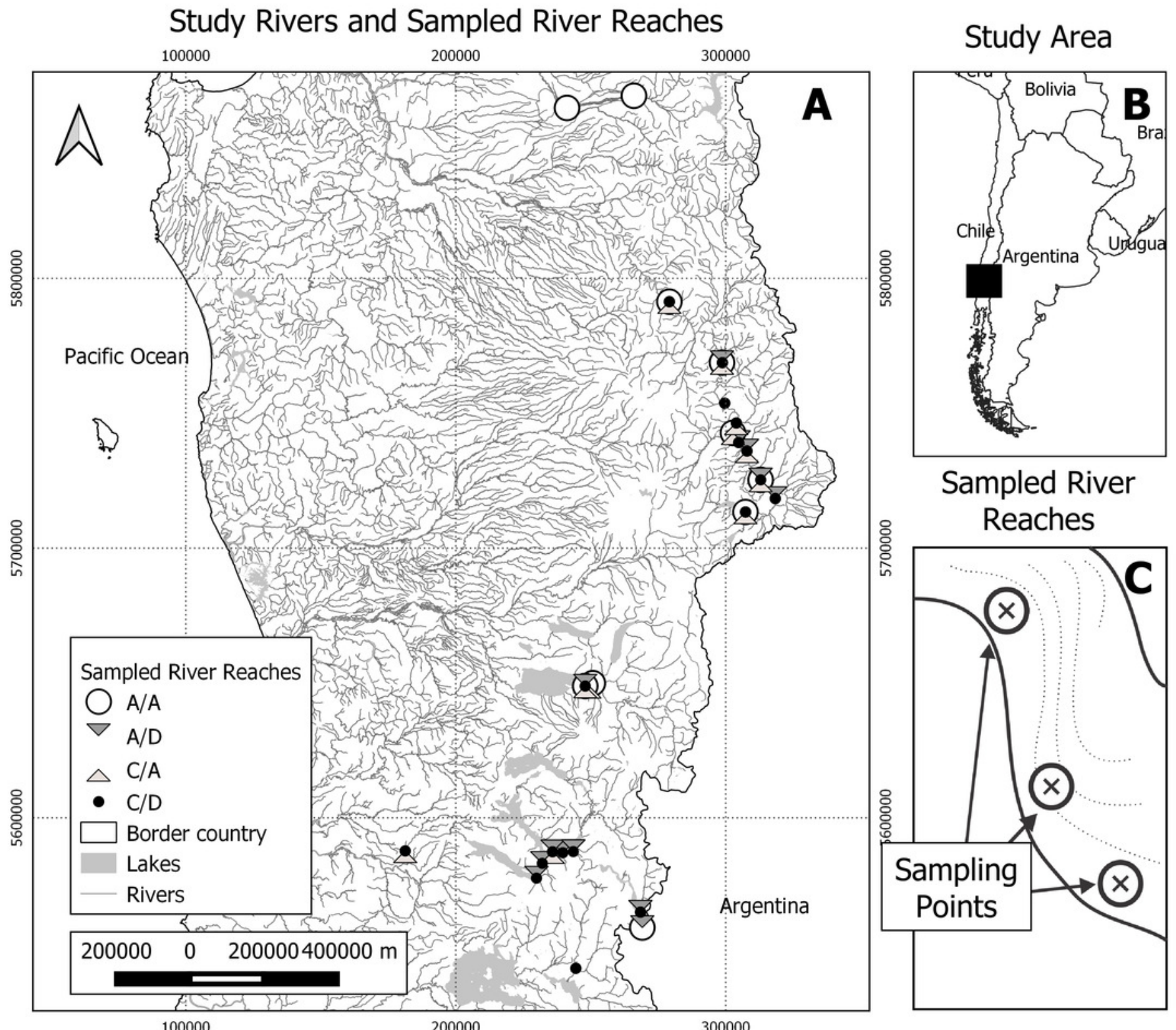


Figure 2

Graphs of the relationship between mat thickness and presence/absence of Cymbella spp. and D. geminata

A) Boxplot thickness in the presence (P) or absence (A) of Cymbella sp. and D. geminata. Letters above ( $a, b$ and $c$ ) represent the homogeneous groups of the tukey test. B) Graph of the interaction between presence and absence of Cymbella spp. and D. geminata against the average mat thickness.
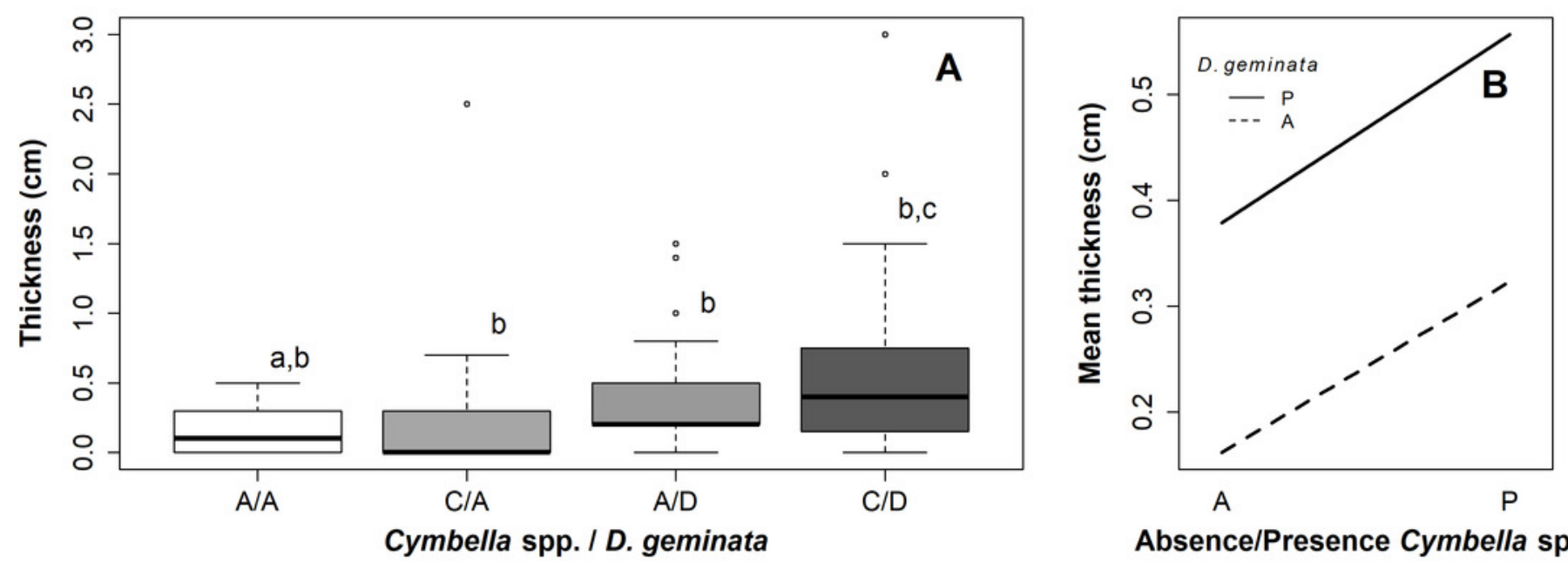

Absence/Presence Cymbella spp. 
Figure 3

Graphs of the relationship between mat thickness and cell density of Cymbella spp. and D. geminata.

Mat thickness as a function of cell density of (A) Cymbella spp. and (B) D. geminata. C) Smooth Surface model of mat thickness in cell density of Cymbella spp. versus cell density of D. geminata plot. Smooth Surface is significant ( $p$ value $=0.03$ ) and accounts for $8.3 \%$ of the variance.

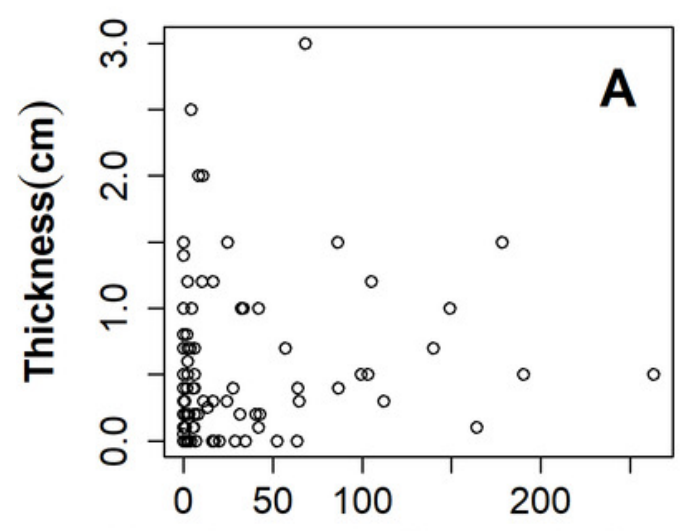

Density Cymbella spp. (cel/mm³)

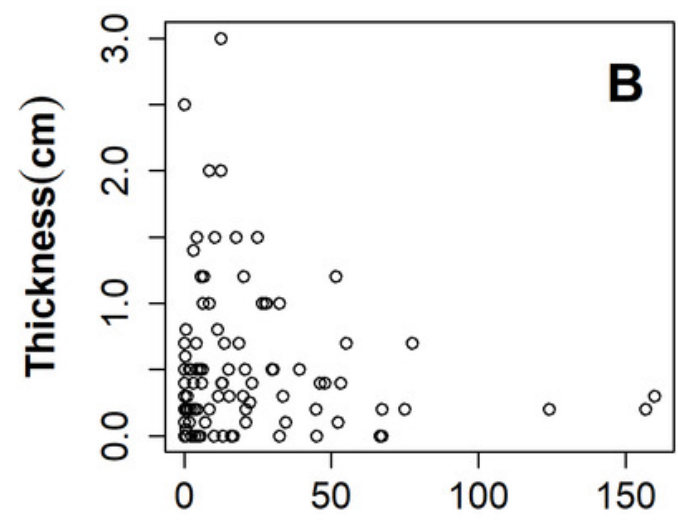

Density D. geminata (cel/mm $\left.\mathrm{mm}^{3}\right)$

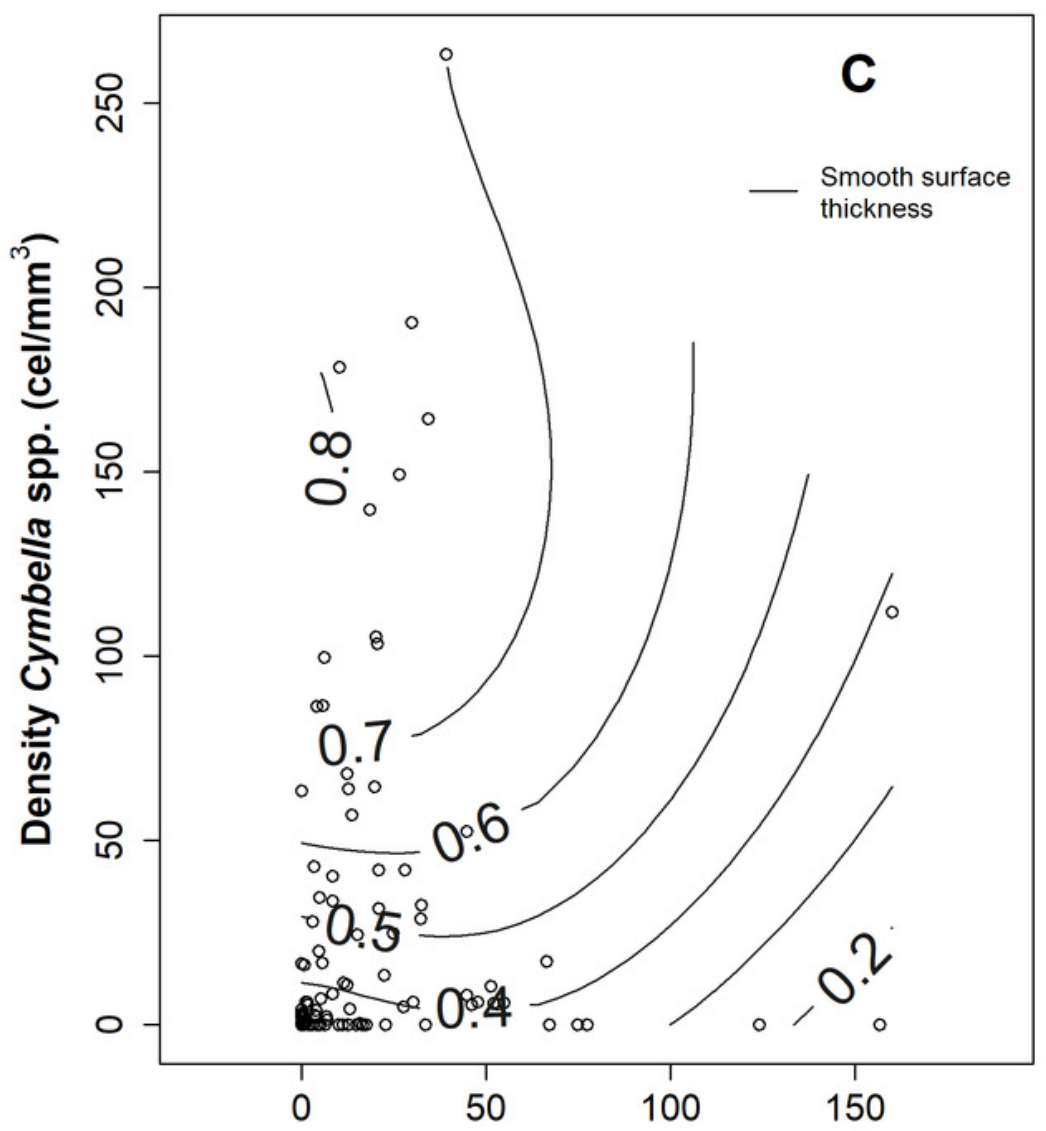

Density D. geminata $\left(\mathrm{cel} / \mathrm{mm}^{3}\right)$ 


\section{Figure 4}

Boxplot of cellular density and mat thickness according to the presence/absence of $D$. geminata and Cymbella spp and sampling season

Samples were categorized as presence only (C/A - Cymbella spp. alone) or (A/D - D. geminata alone); the presence of both (C/D) and, the absence of both taxa (A/A). A) Cymbella spp. density on spring. Sites on presence ofD. geminataand Cymbella spp. showed a peak of Cymbella spp. density. B) D. geminata density on spring. Sites on presence of $D$. geminatawere higher density. C) Mat thickness on spring. Only A/A sites showed lower mat thickness. D) Cymbella spp. density on autumn. Sites on presence ofD. geminataand Cymbella spp. showed a peak of Cymbella spp. density. E) D. geminata density on autumn. Sites on the presence ofD. geminata and Cymbella spp.showed higher density. C) Mat thickness on autumn. All sites showed similar thickness, being higher on A/D sites.

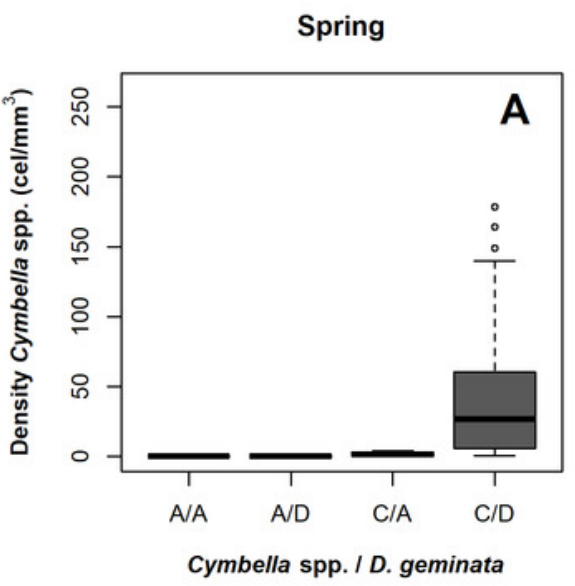

Autumn

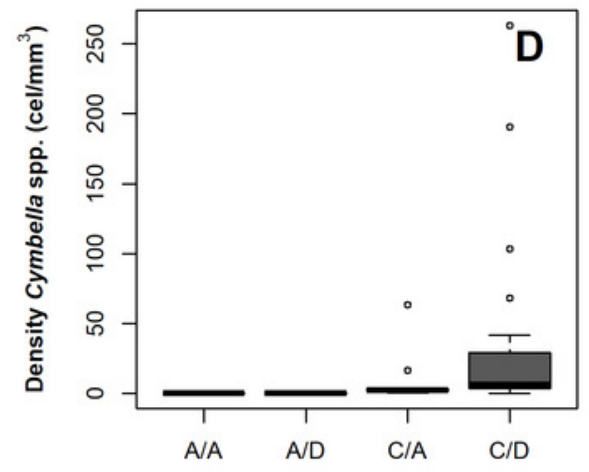

Spring

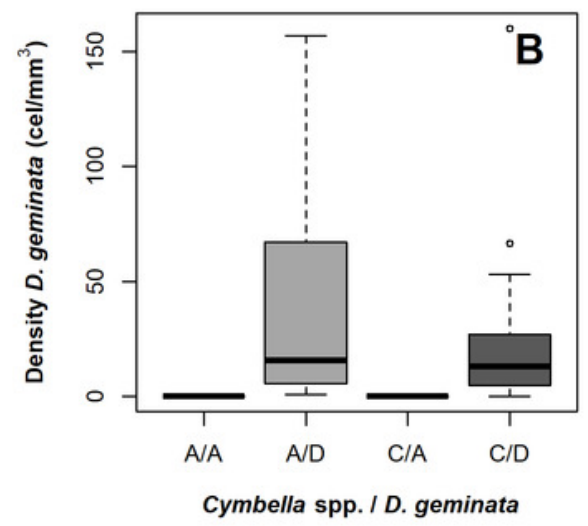

Autumn

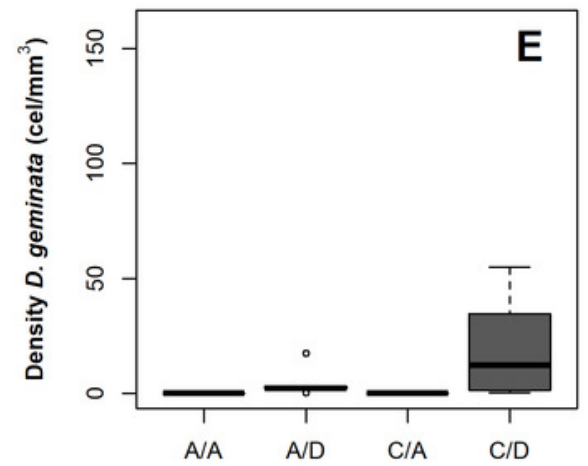

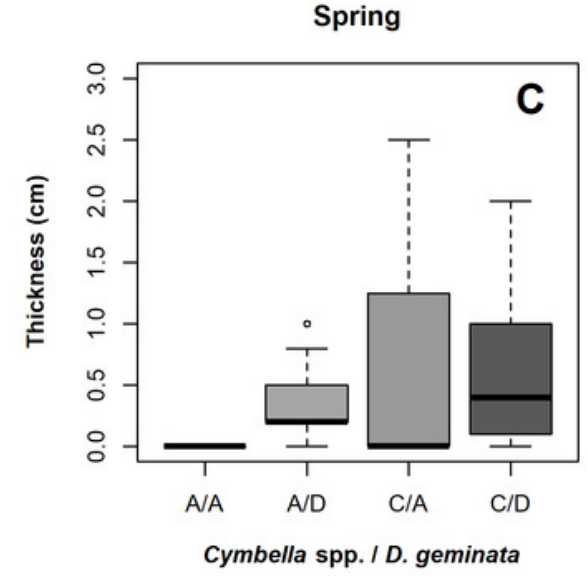

Autumn

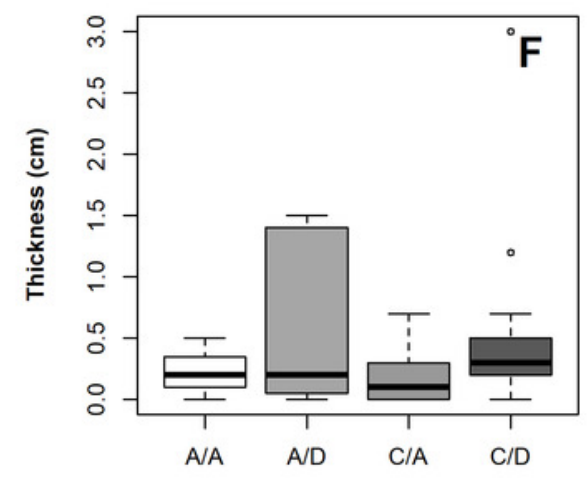

Cymbella spp. I D. geminata 
Figure 5

LDA approach.

Result to LDA analysis. First axis explained $84.5 \%$ of variance, and second axis explained $10 \%$ of variance. Ellipse represent interval confidence estimated by Euclidian equation.

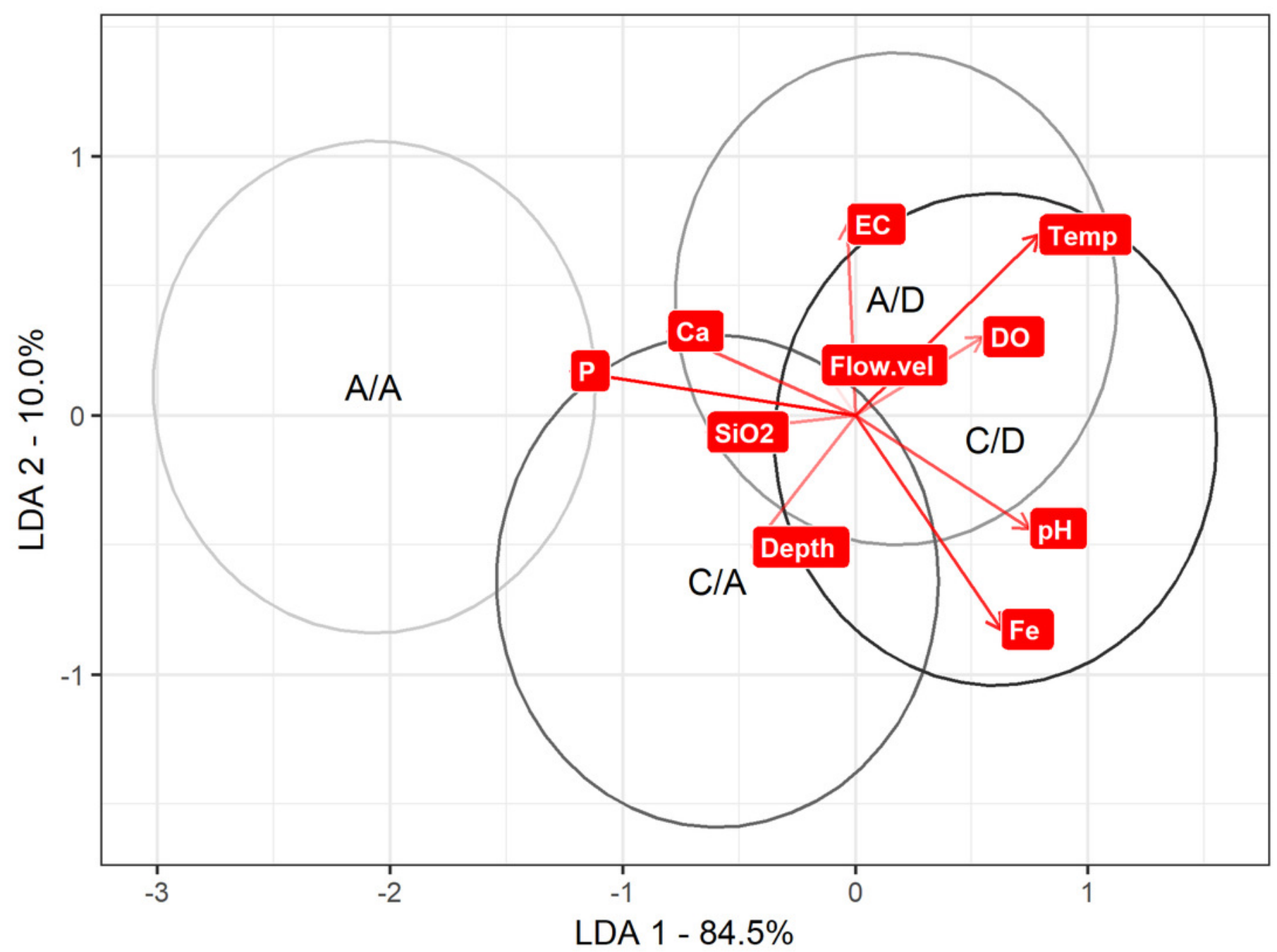




\section{Figure 6}

Boxplot of physical and chemical conditions per river reach sampled according to the presence/absence of $D$. geminata and Cymbella spp. and sampling season.

Samples were categorized as presence only (C/A -Cymbellaspp. alone) or (A/D -D. geminataalone); the presence of both (C/D) and, the absence of both taxa (A/A). To sampling season, a - Autumn and s - Spring.A) Water temperature. Sites in the presence of $D$. geminatadiffer from other sites during spring. B) Water conductivity. Sites in the absence of both microalgae during autumn differ from the rest of the categories. C) Total phosphorus. Sites in the absence of both microalgae differ from the rest of the categories considering both seasons. D) Total silica. Sites in the absence of both microalgae during autumn differ from the rest of the categories. The rest of the chemical variables measured did not yield significant results.
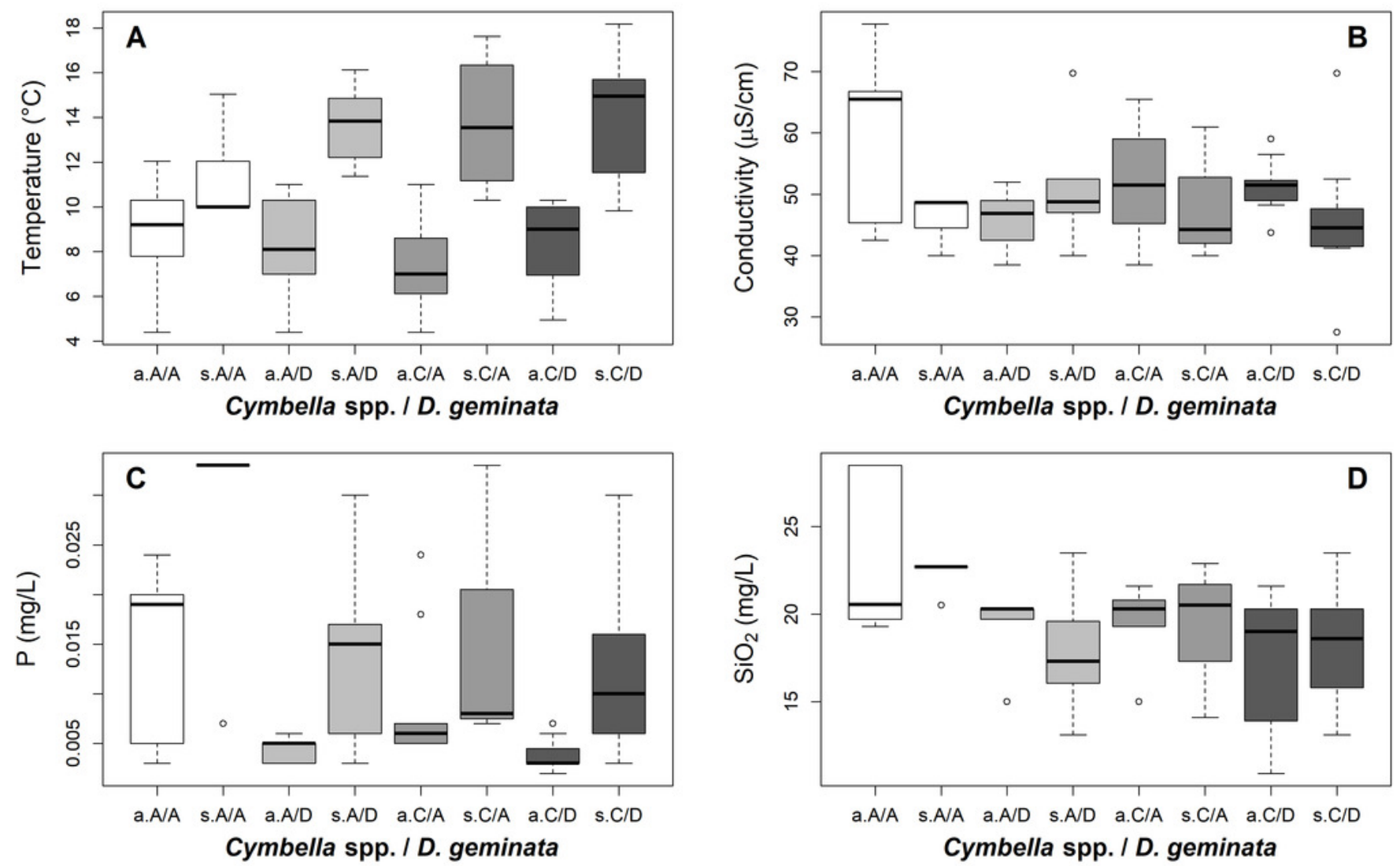
Figure 7

Phosphorus and mat thickness.

Relationship between mat thickness and phosphorous. Each dot is a site categorized by presence only (C/A - Cymbella spp. alone) or (A/D - D. geminata alone), the presence of both (C/D) and, the absence of both taxa (A/A), and sampling season, a - Autumn and s - Spring. Black line represents GAM fit model, and gray area is interval confidence. The mostly sites with higher mat occurred during spring, with one exception during autumn.

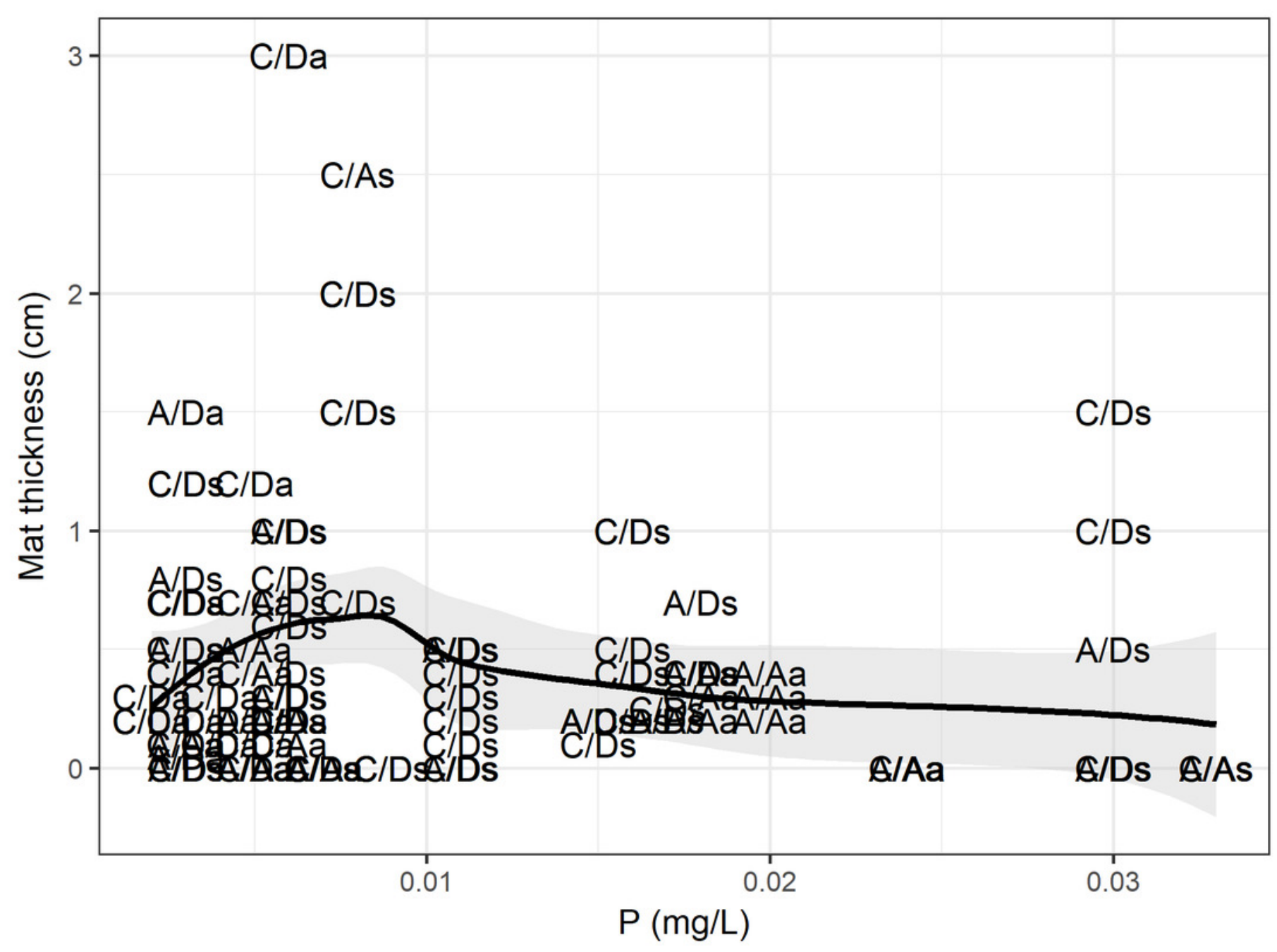




\section{Table $\mathbf{1}$ (on next page)}

\section{Results of Linear Discriminate Analysis (LDA) and Random Forest.}

Column two shows participation by each predictor variable on the first axis of LDA analysis. Column three shows the participation percentage of each variable in the model generated by Random Forest. Column two, LDA to discriminate physical and chemical variables between presence/absence D. geminata and Cymbella spp. Categories (A/A - C/A - A/D - C/D); Phosphorus and temperature were the most relevant variables. Column three, Random Forest to determine the discriminatory capacity of physical, chemical and biological variables on mat thickness; most relevant variables were $D$. geminata density, Cymbella spp. Density, pH, water column depth and $\mathrm{SiO}_{2}$. 
1 Table 1. Results of Linear Discriminate Analysis (LDA) and Random Forest. Column two shows 2 participation by each predictor variable on the first axis of LDA analysis. Column three shows the 3 participation percentage of each variable in the model generated by Random Forest. Column two, LDA to 4 discriminate physical and chemical variables between presence/absence D. geminata and Cymbella spp. 5 Categories $(\mathrm{A} / \mathrm{A}-\mathrm{C} / \mathrm{A}-\mathrm{A} / \mathrm{D}-\mathrm{C} / \mathrm{D})$; Phosphorus and temperature were the most relevant variables. 6 Column three, Random Forest to determine the discriminatory capacity of physical, chemical and biological 7 variables on mat thickness; most relevant variables were D. geminata density, Cymbella spp. Density, $\mathrm{pH}$, 8 water column depth and $\mathrm{SiO}_{2}$.

\begin{tabular}{|c|c|c|}
\hline Predictor variables & $\begin{array}{l}\text { LDA } 1, \text { Between A/A - } \\
\text { C/A - A/D - C/D }\end{array}$ & $\begin{array}{lr}\text { Random } & \text { Forest, Mat } \\
\text { thickness } & \text { response } \\
\text { variable } & \end{array}$ \\
\hline $\mathrm{Ca}$ & -0.54 & 14.61 \\
\hline $\mathrm{EC}$ & -0.02 & 6.87 \\
\hline $\mathrm{Fe}$ & 0.42 & 3.75 \\
\hline DO & 0.37 & 11.90 \\
\hline $\mathrm{P}$ & -0.82 & 100.00 \\
\hline $\mathrm{pH}$ & 0.50 & 28.44 \\
\hline Water column depth & -0.29 & 23.63 \\
\hline $\mathrm{SiO}_{2}$ & -0.42 & 26.38 \\
\hline Temperature & $\mathbf{0 . 5 3}$ & 12.58 \\
\hline Background flow velocity & -0.10 & 7.43 \\
\hline Sampling season & - & 0.86 \\
\hline Cymbella spp. cell density & - & 29.32 \\
\hline D. geminata cell density & - & 32.38 \\
\hline $\begin{array}{ll}\text { Cymbella } & \text { spp. } \\
\text { Presence/absence } & \end{array}$ & - & 8.23 \\
\hline D. geminata Presence/absence & - & 7.21 \\
\hline
\end{tabular}

